\title{
EVALUASI PENGGUNAAN ANTIBIOTIK PASIEN INFEKSI SALURAN PERNAFASAN AKUT (ISPA) DENGAN METODE ATC/DDD DI PUSKESMAS BEJI DEPOK PERIODE JANUARI-JUNI 2019
}

\author{
Ferry Effendi ${ }^{*}$., Anastasia Evelin ${ }^{2}$ \\ 1. Program Studi Farmasi Sekolah Tinggi Teknologi Industri dan Farmasi Bogor \\ 2. Mahasiswa Program Studi S1 Farmasi Sekolah Tinggi Teknologi Industri dan Farmasi Bogor \\ Korespondensi: ferry@sttif.ac.id
}

\begin{abstract}
ABSTRAK
Prevalensi ISPA yang cukup tinggi di Indonesia mempengaruhi pola penggunaan obat, terutama antibiotik di fasilitas kesehatan. Sekitar 30-80\% pasien diresepkan antibiotik dan penggunaannya tidak rasional, Laporan Tahunan Puskesmas Beji tahun 2018 menunjukkan ISPA merupakan penyakit yang paling banyak ditemukan, yaitu sekitar 30,97\% kasus. Tujuan dari penelitian ini untuk mengetahui evaluasi penggunaan antibiotik pada pasien ISPA di Puskesmas Beji dengan metode Anatomical Therapeutic Chemical (ATC)/Defined Daily Dose (DDD). Penelitian ini dilakukan secara deskriptif dengan desain studi potong lintang (cross sectional). Metode pengumpulan data dilakukan secara retrospektif dengan purposive sampling. Sampel dalam penelitian ini menggunakan rumus slovin diambil dari populasi yang memenuhi kriteria inklusi dan eksklusi. Rekam Medis pasien yang memenuhi kriteris inklusi dan eksklusi sebanyak 104 Rekam medis. Hasil analisis bedasarkan sosiodemografi pasien ISPA terbanyak berjenis kelamin perempuan dan kelompok usia remaja akhir 17-55 tahun. Diagnosa ISPA terbanyak Acute pharyngitis, unspecified. Antibiotik yang digunakan Amoxicillin $500 \mathrm{mg}$, Ciprofloxacin $500 \mathrm{mg}$, Cotrimoxsazole $480 \mathrm{mg}$, Cotrimoxsazole $960 \mathrm{mg}$, Erythromycin $500 \mathrm{mg}$, dan Thiamphenicol 500 mg. Penggunaan Obat dinyatakan nilai DDD/1000/pasien yaitu Amoxicillin 500 mg (16,2062); Ciprofloxacin $500 \mathrm{mg}(1,1039)$; Cotrimoxsazole $480 \mathrm{mg}$ (0.460); Cotrimoxsazole $960 \mathrm{mg}$ (0.3683); Erythromycin $500 \mathrm{mg}$ 0,2762); dan Thiamphenicol $500 \mathrm{mg}(0,5524)$. Obat yang menyusun segmen DU90\%, yaituAmoxicillin $500 \mathrm{mg}(85.44 \%)$ dan Ciprofloxacin $500 \mathrm{mg}$ $(5.83 \%)$.
\end{abstract}

Kata kunci: ATC/DDD, DDD1000/pasien/hari, DU90\%, Evaluasi Penggunaan Antibiotik, Infeksi Saluran Pernafasan Akut (ISPA).

\begin{abstract}
The prevalence of ISPA which is quite high in Indonesia affects the pattern of use of drugs, especially antibiotiks in health facilities. About $30-80 \%$ of patients prescribed antibiotiks and their use is irrational, the annual report BejiPuskesmas year 2018 showed that ISPA is the most commonly found disease, which is about $30.97 \%$ of cases. The purpose of this research is to know the evaluation of antibiotik use in ISPA patients in BejiPuskesmas with the Anatomical Therapeutic Chemical (ATC)/Defined Daily Dose (DDD) method. The study was conducted descriptively with a cross sectional study design. Data collection methods are performed retrospectively with purposive sampling. The samples in this study used the Slovin formula taken from the population that meet the inclusion and exclusion criteria. There were 104 medical record of who met the inclusion and exclusion criteria. The results of the analysis based on the sociodemography of most female ISPA patients and the late adolescent age group 17-55 years. Most ISPA diagnosis Acute pharyngitis, unspecified. Antibiotiks used Amoxcillin $500 \mathrm{mg}$, Ciprofloxacin $500 \mathrm{mg}$, Cotrimoksazole $480 \mathrm{mg}$, Cotrimoksazole $960 \mathrm{mg}$, erythromycin $500 \mathrm{mg}$, and Tiamphenicol $500 \mathrm{mg}$. Drug use expressed the value of DDD/1000/patients namely Amoxcillin $500 \mathrm{mg}$ (16.2062); Ciprofloxacin $500 \mathrm{mg}$ (1.1039); Cotrimoksazole $480 \mathrm{mg}$ (0460);

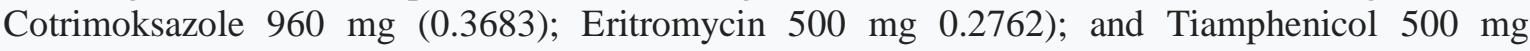
(0.5524). The drug that composes the segment DU90\%, namely Amoxcillin $500 \mathrm{mg}(85.44 \%)$ and Ciprofloxacin $500 \mathrm{mg}(5.83 \%)$.
\end{abstract}




\section{9 | Ferry Effendi et al., (Evaluasi Penggunaan Antibiotik Pasien Infeksi ...)}

Keywords: ATC/DDD,DDD/1000/patients/day, DU90\%, evaluation of antibiotic use, Infection Acute Respiratory Tract (ISPA)

\section{PENDAHULUAN}

Antibiotik merupakan obat yang paling banyak digunakan pada infeksi yang disebabkan oleh bakteri. Berbagai studi menemukan bahwa sekitar 40-62\% antibiotik digunakan secara tidak tepat antara lain untuk penyakit-penyakit yang sebenarnya tidak memerlukan antibiotik. Intensitas penggunaan antibiotik yang relatif tinggi menimbulkan berbagai permasalahan dan merupakan ancaman global bagi kesehatan terutama resistensi bakteri terhadap antibiotika dan munculnya efek obat yang tidak dikehendaki. Hal ini terjadi akibat penggunaan antibiotik yang tidak bijak dan penerapan kewaspadaan standar yang tidak benar di fasilitas pelayanan kesehatan[1].

Infeksi Saluran Pernapasan Akut merupakan suatu infeksi akut pada struktur saluran napas yang mengganggu proses pertukaran gas mulai dari bagian hidung sampai alveoli termasuk adneksanya (sinus, rongga telinga tengah, pleura). Penyebab infeksi saluran pernapasan secara umum adalah berbagai mikroorganisme, namun sebagian besar disebabkan oleh infeksi virus dan bakteri[2].

Prevalensi ISPA di Indonesia pada tahun 2018, yaitu sekitar 9,3\% bedasarkan diagnosis tenaga kesehatan dan keluhan penduduk. ISPA menjadi salah satu faktor kunjungan pasien untuk datang ke puskesmas (40-60\%) dan rumah sakit (15-30\%). Prevalensi ISPA di Jawa Barat pada tahun 2018 memiliki persentase sekitar 12\%[3]

Evaluasi penggunaan antibiotik dapat dikaji secara kuantitas dan kualitas yaitu dengan melihat jenis, jumlah,dosis cara pemberian antibiotik dan lain-lain.Semakin kecil kuantitas antibiotik yang digunakan menunjukkan semakin selektif penggunaan antibiotik, sehingga lebih mendekati penggunaan antibiotik yang bijak[4].

Metode ATC/DDD Anatomical

Therapeutic Chemical (ATC) Defined Daily Dose (DDD) merupakan salah satu metode yang direkomendasikan oleh World Health Organization (WHO) dan Kementerian Kesehatan Republik Indonesia.
Tujuan dari sistem ATC/DDD adalah sebagai sarana untuk penelitian penggunaan obat dalam upaya meningkatkan kualitas penggunaan obat[5].

Metode Drug Utilization 90\% (DU 90\%) merupakan metoda yang menunjukkan pengelompokan obat yang termasuk dalam kategori $90 \%$ penggunaan yang sering digunakan bersama dengan analisis penggunaan obat ATC/DDD.

Penilaian terhadap obat yang masuk kedalam segmen $90 \%$ diperlukan untuk menekankan segmen obat yang dikaji kaitannya dengan evaluasi pengendalian penggunaan dan perencanaan pengadaan obat[6]

Laporan Tahunan Puskesmas Beji tahun 2018 menunjukkan ISPA merupakan penyakit yang paling banyak ditemukan, yaitu sekitar $30,97 \%$ kasus. Tingginya kasus ISPA tersebut juga dapat meningkatkan penggunaan antibiotik.

Evaluasi penggunaan antibiotik perlu dilakukan untuk mengetahui kesesuaian penggunaan antibiotik dengan daftar obat terpilih serta untuk menghindari adanya resistensi obat yang digunakan dalam pengobatan ISPA.

\section{METODE PENELITIAN}

Penelitian ini menggunakan rancangan penelitian cross sectional dengan pengambilan data secara retrospektif. Metode pengambilan data melalui rekam medis menggunakan Sistem Informasi Manajemen Puskesmas (Simpus) dimana terdapat kode ICD-10 Data kuantitas penggunaan antibiotik dengan kode ATC diambil dan diolah dengan menggunakan metode ATC/DDD dengan satuan unit DDD/1000 pasien/hari dan Drug Utilization 90\% (DU90\%) digunakan untuk menilai kualitas penggunaan obat. Statistik deskriptif digunakan untuk menyajikan data dan menganalisis data.

Populasi dalam penelitian ini adalah seluruh data pasien ISPA yang mendapat antibiotik, berusia 17-55 tahun dan merupakan kunjungan pertama menjalani pengobatan di 
10 | Ferry Effendi et al., (Evaluasi Penggunaan Antibiotik Pasien Infeksi ...)

Puskesmas Beji periode Januari -Juni 2019 sebanyak 150 rekam medis.

ATC/DDD (Anatomical Therapeutic Chemical

Sampel pada penelitian ini diambil dengan

Teknik pengambilan sampel dengan cara purposive sampling yang ada sehingga jumlah sampel yang digunakan sebanyak 104 rekam medis yang memenuhi kriteria inklusi dan ekslusi .

Data yang diperoleh ditampilkan secara deskriptif meliputi karakteristik demografi pasien (usia, jenis kelamin, Jenis Antibiotik yang digunakan pada pasien ISPA), Profil Pola Diagnosis padaPasien ISPA, Evaluasi penggunaan antibiotik dengan metode kuantitaf

(ATC)/DefinedDaily Dose (DDD), DDD/1000/pasien/hari dan metode kualitatif DU90\% (Drug Utilization).

\section{HASIL DAN PEMBAHASAN}

\section{Karakeristik pasien}

Pengamatan dilakukan bedasarkan karateristik pasien terhadap seluruh sampel, yaitu 104 rekam medis pasien ISPA. Distribusi pasien ISPA paling banyak berjenis kelamin perempuan $(51,92 \%)$ dan kelompok usia 17-25 tahun $(37,50 \%)$.

Tabel 1. KarakteristikPasien

\begin{tabular}{|c|c|c|c|}
\hline KarakteristikPasien & Kategori & JumlahPasien & Persentase $(\%)$ \\
\hline \multirow[t]{2}{*}{ JenisKelamin } & Laki-laki & 50 & 48.08 \\
\hline & Perempuan & 54 & 51.92 \\
\hline $\begin{array}{c}\text { Usia } \\
\text { Menurut }\end{array}$ & 17-25 Tahun & 39 & 37.50 \\
\hline \multirow[t]{3}{*}{$\begin{array}{l}\text { Depkes RI } \\
(2009)\end{array}$} & 26-35 Tahun & 27 & 25.96 \\
\hline & 36-45 Tahun & 20 & 19.23 \\
\hline & 46-55 Tahun & 18 & 17.31 \\
\hline
\end{tabular}

\begin{abstract}
Karakteristik pasien ISPA bedasarkan jenis kelamin Hasil data yang diperoleh menunjukkan prevalensi ISPA lebih banyak terjadi pada perempuan dibandingkan laki-laki, tetapi dalam jumlah yang tidak terlalu signifikan.
\end{abstract}

Penyebab terjadinya infeksi adalah penurunan fungsi sistem imun yang dapat disebabkan oleh beberapa faktor. Salah satu faktor stimulasi dari luar, yaitu stres. Wanita lebih mudah stress dibandingkan laki-laki. Stres dapat berupa stres fisik maupun psikis dan emosi. Adanya tekanan tersebut memicu respon tubuh untuk membantu mengatasi stres.

Hasil penelitian menunjukkan bahwa angka kejadian ISPA terbanyak pada usia 17-25 tahun. Hal ini disebabkan karena jumlah penduduk pada usia 17-25 tahun sekitar 10.973 jiwa dari 78.880 jiwa $(13,91 \%)$ di wilayah Beji Depok, juga dikarenakan wilayah kerja Puskesmas Beji dekat dengan beberapa perguruan tinggi. Penggunaan antibiotik di Puskesmas Beji terdiri dari 6 jenis antibiotik. Antibiotik yang paling banyak digunakan 
11 | Ferry Effendi et al., (Evaluasi Penggunaan Antibiotik Pasien Infeksi ...)

adalah Amoxcillin $500 \mathrm{mg}$ sebanyak 1320 tablet $\quad$ (87,42\%).

Tabel 2. Daftar penggunaan antibiotik pada pasien ISPA

\begin{tabular}{|c|c|c|c|c|}
\hline Antibiotik & Golongan & $\begin{array}{l}\text { Unit DDD } \\
(\mathrm{mg})\end{array}$ & $\begin{array}{l}\text { Jumlah } \\
\text { Obat }\end{array}$ & $\begin{array}{l}\text { Persentase } \\
(\%)\end{array}$ \\
\hline Amoxcillin $500 \mathrm{mg}$ & BetaLaktam (Penisilin) & 1500 & 1320 & 87.42 \\
\hline Ciprofloxacin $500 \mathrm{mg}$ & Kuinolon & 1000 & 60 & 3.98 \\
\hline $\begin{array}{l}\text { Cotrimoxsazole } \\
\mathrm{mg}\end{array}$ & $\begin{array}{l}\text { Sulfametoksazol- } \\
\text { Trimetroprim }\end{array}$ & 1920 & 50 & 3.31 \\
\hline $\begin{array}{l}\text { Cotrimoxsazole } \\
\mathrm{mg}\end{array}$ & $\begin{array}{l}\text { Sulfametoksazol- } \\
\text { Trimetroprim }\end{array}$ & 1920 & 20 & 1.32 \\
\hline \multirow{2}{*}{$\begin{array}{l}\text { Erythromycin } 500 \mathrm{mg} \\
\text { Thiamphenicol } 500 \mathrm{mg}\end{array}$} & Makrolid & 1000 & 15 & 0.99 \\
\hline & Amfenikol & 1500 & 45 & 2.98 \\
\hline & & Total & 1510 & 100 \\
\hline
\end{tabular}

Penggunaan antibiotik didominasi oleh amoksisilin karena merupakan spektrum yang luas dan pada umumnya menjadi lini pertama pada pasien ISPA. Amoksisilin bermanfaat terhadap berbagai jenis infeksi bakteri, tetapi hal ini juga dapat menyebabkan amoksisilin memiliki tingkat resistensi yang tinggi. Penggunaan antibiotik yang bijaksana erat kaitannya dengan pemilihan antibiotik yang memiliki spektrum sempit dengan indikasi yang tepat, dosis, serta penggunaan tidak lebih lama dari yang dibutuhkan [7].

\section{Profil Pola Diagnosis pada Pasien ISPA}

Hasil penelitian pola diagnosis untuk pasien ISPA terdiri dari 11 jenis diagnosis menurut kode $I C D-10$ diagnosis yang paling banyak terdapat di Puskesmas Beji adalah Acute pharyngitis, unspecified sebanyak 46 diagnosis dari 104 diagnosis $(44,23 \%)$.

Tabel 3. Daftar penggunaan antibiotik pada pasien ISPA

\begin{tabular}{|c|c|c|}
\hline DIAGNOSIS & JUMLAH PASIEN & $\begin{array}{c}\text { PERSENTASE } \\
(\boldsymbol{\%})\end{array}$ \\
\hline NASOPHARYNGITIS & 10 & 9.62 \\
\hline \multicolumn{3}{|l|}{$[C O M M O N C O L D]$} \\
\hline ACUTE MAXILLARY SINUSITIS & 3 & 2.88 \\
\hline ACUTE PHARYNGITIS, UNSPECIFIED & 46 & 44.23 \\
\hline ACUTE TONSILLITIS, UNSPECIFIED & 8 & 7.69 \\
\hline ACUTE LARYNGOPHARYNGITIS & 7 & 6.73 \\
\hline RESPIRATORY & 21 & 20.19 \\
\hline \multicolumn{3}{|l|}{ INFECTION, UNSPECIFIED } \\
\hline INFLUENZA & 2 & 1.92 \\
\hline MANIFESTATIONS, & & \\
\hline \multicolumn{3}{|l|}{ VIRUS NOT IDENTIFIED } \\
\hline PNEUMONIA & 1 & 0.96 \\
\hline BRONCHOPNEUMONIA, & 2 & 1.92 \\
\hline ACUTE BRONCHITIS, UNSPECIFIED & 2 & 1.92 \\
\hline ALLERGIC RHINITIS & 2 & 1.92 \\
\hline TOTAL & 104 & 100 \\
\hline
\end{tabular}


12 | Ferry Effendi et al., (Evaluasi Penggunaan Antibiotik Pasien Infeksi ...)

Penegakkan diagnosis ISPA yang di lakukan oleh dokter berdasarkan anamnesis dan pemeriksaan fisik [1].

Acute pharyngitis, unspecified atau disebut juga Faringitis akut adalah peradangan pada mukosa faring dan jaringan limfoid di sekitarnya akibat infeksi bakteri atau virus. Faringitis akut merupakan penyakit infeksi saluran pernafasan terbanyak yang terjadi pada pasien di Puskesmas Beji.

\section{Nilai DDD dan nilai DDD/1000/pasien/hari}

Hasil perhitungan nilai DDD antibiotik terbanyak yaitu Amoxcillin (440).

Tabel 4. DDD dan DDD/1000 pasien/hari

\begin{tabular}{lllllll}
\hline Antibiotik & $\begin{array}{l}\text { Kode } \\
\text { ATC }\end{array}$ & $\begin{array}{l}\text { Unit } \\
\text { DDD } \\
(\mathrm{mg})\end{array}$ & $\begin{array}{l}\text { Jumlah } \\
\text { obat }\end{array}$ & $\begin{array}{l}\text { Jumlah } \\
(\mathrm{mg})\end{array}$ & $\begin{array}{l}\text { Nilai } \\
\text { DDD }\end{array}$ & DDD/1000/pasien/hari \\
\hline $\begin{array}{l}\text { Amoxcillin500 } \\
\text { mg }\end{array}$ & J01CA04 & 1500 & 1320 & 500 & 440 & 23,37441564 \\
$\begin{array}{l}\text { Ciprofloxacin } \\
\text { 500 mg }\end{array}$ & J01MA02 & 1000 & 60 & 500 & 30 & 1,593710157 \\
$\begin{array}{l}\text { Cotrimoxsazole } \\
480 \mathrm{mg}\end{array}$ & J01EE01 & 1920 & 50 & 480 & 12.5 & 0,664045899 \\
$\begin{array}{l}\text { Cotrimoxsazole } \\
960 \mathrm{mg}\end{array}$ & J01EE01 & 1920 & 20 & 960 & 10 & 0,531236719 \\
$\begin{array}{l}\text { Erythromycin } \\
\text { 500 mg }\end{array}$ & J01FA01 & 1000 & 15 & 500 & 7.5 & 0,398427539 \\
$\begin{array}{l}\text { Tiamphenicol500 } \\
\text { mg }\end{array}$ & J01BA02 & 1500 & 45 & 500 & 15 & 0,796855079 \\
\hline & & & & TOTAL & 515 & 27,35869103 \\
\hline
\end{tabular}

Berdasarkan hasil perhitungan nilai DDD dan nilai DDD/1000/pasien/hari terbesar dimiliki oleh amoksisilin. Hal ini dikarenakan penggunaan antibiotik terbanyak adalah amoksisilin sehingga memiliki nilai DDD terbesar. Semakin besar nilai DDD maka semakin besar pula penggunaan obat tersebut. Nilai DDD amoksisilin 440 hal ini menunjukkan bahwa dalam enam bulan ratarata penggunaan dosis amoksisilin sebanyak 440 unit.
Nilai DDD/1000/pasien/hari amoksisilin di Puskesmas Beji (23,374DDD/1000/pasien/hari) menunjukkan bahwa $2,337 \%$ perseribu populasi menggunakan amoksisilin setiap harinya.

\section{Drug Utilization 90\% (DU90\%)}

Drug Utilization 90\% dihitung bedasarkan besarnya nilai DDD antibiotik yang digunakan. Antibiotik yang masuk kedalam segmen DU90\% adalah Amoxcillin dan Ciprofloxacin.

Tabel 5..Drug Utilization 90\%

\begin{tabular}{llllll}
\hline Antibiotik & KODE ATC & $\begin{array}{l}\text { UNIT } \\
\text { DDD }\end{array}$ & $\begin{array}{l}\text { NILAI } \\
\text { DDD }\end{array}$ & $\begin{array}{l}\text { Persentase } \\
\text { DU90\% }\end{array}$ & $\begin{array}{l}\text { Persentase } \\
\text { kumulatif }\end{array}$ \\
\hline Amoxcillin 500 mg & J01CA04 & 1500 & 440 & $85.44 \%$ & $85 \%$ \\
Ciprofloxacin 500 mg & J01MA02 & 1000 & 30 & $5.83 \%$ & $91 \%$ \\
Thiamphenicol 500 mg & J01BA02 & 1500 & 15 & $2.91 \%$ & $94 \%$ \\
Cotrimoxsazole 480 mg & J01EE01 & 1920 & 12.5 & $2.43 \%$ & $97 \%$ \\
Cotrimoxsazole 960 mg & J01EE01 & 1920 & 10 & $1.94 \%$ & $99 \%$ \\
Erythromycin 500 mg & J01FA01 & 1000 & 7.5 & $1.46 \%$ & $100 \%$ \\
\hline & & Total & 515 & $100 \%$ & \\
\hline
\end{tabular}


13 | Ferry Effendi et al., (Evaluasi Penggunaan Antibiotik Pasien Infeksi ...)

DU90\% merupakan penilaian kualitatif terhadap kuantitas penggunaan obat. Berdasarkan analisis kualitatif, obat yang masuk kedalam segmen DU90\% adalah Amoxcillin $500 \mathrm{mg}$ dan Ciprofloxacin $500 \mathrm{mg}$, sedangkan obat yang masuk segmen DU10\% adalah Thiamphenicol $500 \mathrm{mg}$, Cotrimoxsazole $480 \mathrm{mg}$, Cotrimoxsazole $960 \mathrm{mg}$ dan Erythromycin $500 \mathrm{mg}$. Data tersebut menunjukkan efektivitas penggunaan obat yang baik karena semakin sedikit jenis obat yang digunakan dalam segmen DU90\% maka kualitas peresepan semakin baik [8]. Kualitas penggunaan antibiotik yang digunakan sudah cukup baik, karena $90 \%$ jumlah dari obat yang diresepkan sudah sesuai dengan pedoman penulisan resep yang digunakan [9].

Antibiotik yang masuk dalam DU 90\% memiliki potensi besar terhadap terjadinya resistensi.

\section{SIMPULAN}

1. Pasien ISPA lebih banyak berjenis kelamin perempuan $(51,92 \%)$ dengan kelompok usia 17-25 tahun $(37,50 \%)$.

2. Pola Profil Diagnosis ISPA yang paling banyak adalah Acute pharyngitis, unspecified (44,23\%).

3. Nilai DDD Antibiotik terbanyak adalah Amoksisilin $500 \mathrm{mg}$ dengan nilai 440 DDD dan 23,3744 DDD/1000/pasien/hari.

4. Antibiotik yang menyusun segmen DU90\%, yaitu Amoxcillin $500 \mathrm{mg}(85,44 \%)$ dan Ciprofloxsacin $500 \mathrm{mg}(5,83 \%)$.

\section{DAFTAR PUSTAKA}

[1] [Kemenkes] Kementerian Kesehatan Republik Indonesia. 2011. Pedoman Umum Penggunaan Antibiotik. Jakarta : Bakti Husada.

[2] Corwin E.J., 2009, Buku Saku Patofisiologi, Diterjemahkan Oleh Yudha, E. K., Handbook of pathophysiology, EGC, Jakarta, pp. 441-521.
[3] Riset Kesehatan Dasar (Riskesdas) (2018). Badan Penelitian dan Pengembangan Kesehatan Kementerian RI tahun 2018. http://www.depkes.go.id/resources/downloa d/infoterkini/materi_rakorpop_2018/Hasil\% 20Riskesdas\%202018.pdf-Diakses Oktober 2019.

[4] Laras, W.N, 2012, Kuantitas penggunaan Antibiotik Bangsal Bedah dan ObstetriGinekologi RSUP Dr. Kariadi setelah kampanye PP PPRA [skripsi], Semarang: UniversitasDiponegoro.

[5] Guidelines for ATC, 2013, Classification and DDD assignment. Norway: Norwegian Institute ofPublic Health. ;16:32-5.

[6] Mahmudah, F., Sumiwi, S., \& Hartini, S. 2011. Studi Penggunaan Antibiotik Berdasarkan ATC/DDD dan DU 90 di Bagian Bedah Digestif di Salah Satu Rumah Sakit di Bandung. Jurnal Farmasi Klinik Indonesia, 293-298.

[7] Negara, Surya. 2014. Analisis Implementasi Kebijakan Penggunaan Antibiotika Rasional Untuk Mencegah Resistensi Antibiotika di RSUP Sanglah Denpasar: Studi kasus Infeksi Methicillin Resistant Staphylococcus Aureus. Jurnal ARSI, 42-50.

[8] Goossens H, Ferech M, Vander SR, Elseviers M. Outpatient antibiotic use in Europe and association with resistance: a cross-national database study. The Lancet. 2005;365(9459):579-87. doi: 10.1016/ S0 140-6736(05)17907-0

[9] World Health Organization. 2003. Drug utilization and their applications: introduction to drug utilization research. Oslo: World Health Organization. 